Author's Pre-Publication Copy. For the full paper, please download Hristov, D., Naumov, N. \& Petrova, P. (2018) Historic Gardens: English Heritage Perspective, Tourism Review 73(2), 199-215.

\title{
Interpretation in Historic Gardens: English Heritage Perspective
}

\begin{abstract}
This paper provides an exploratory investigation into contemporary interpretation methods used in historic gardens and their fundamental role in enhancing the visitor experience, and sense of a place. The importance of conceptualising and operationalising interpretation in historic gardens has received relatively little attention across the extant body of heritage interpretation literature. English Heritage's Wrest Park - which is amongst England's most prominent historic gardens - is used as a case study. A series of semi-structured interviews (n $=65$ ) with Wrest Park visitors - who had the opportunity to experience new interpretation methods provided on-site - have been carried out in an attempt to explore their sense of place through interpretation. The research suggests that interpretation has a fundamental role to play in 'telling the story' of historic gardens with $92.5 \%$ of the sample understanding elements of the place's history, significance and evolution. The findings further suggest the presence of two distinct visitor typologies - history explorers and leisure seekers. The paper concludes with a call for more empirical investigations of interpretation techniques in historic gardens and their contribution to enhancing the visitor experience and sense of place.
\end{abstract}

Keywords: Interpretation, Historic Gardens, Audience Development, English Heritage, Wrest Park

\section{Introduction}

Located within the broader umbrella of cultural landscapes (Halbrooks, 2005), historic gardens are as much part of our heritage as our historic towns, architecture or literature (Laurie, 2007). Broadly defined as "an architectural and horticultural composition of interest to the public from the historical and artistic point of view" (ICOMOS Florence Charter, 1982), historic gardens have been thriving over the past few decades (Lambert \& Lovie, 2014; Mawrey \& Groves, 2010), particularly in the United Kingdom, where visiting historic gardens has become a traditional leisure activity (Gallaher (1983).

Large-scale heritage restorations and developments, through the Heritage Lottery Fund in the UK have largely changed the appeal of historic gardens from places for relaxation and educational activities to visitor attractions with a considerable potential to attract a large number of tourists and visitors (Connell, 2005; Evans, 2001; Fox, 2007). Like other heritage sites (e.g. historic castles), historic gardens have started to actively promote 'heritage experiences' and put an emphasis on the process of engagement between the involvement of senses and emotions as integral parts of the tourism product (Naumov, 2015). 
Such developments call for the adoption of new approaches to visitor management (Cheng, Jin and Wong, 2014) and the implementation of methods for audience development in historic gardens.

According to Arts Council England (2011), audience development can be explained as a set of activities aimed at understanding and knowing vis-à-vis segmentation and pull factors/motivations of existing and potential audiences with the intention to develop sustainable, long-term relationships with visitors in heritage sites. Arguably, understanding audience background/profiles is key to implementing successful interpretation as it enhances visitor learning, appreciation and enjoyment (Yamada and Knapp, 2009).

Nurturing knowledge development and appreciation of the past from audiences brings into the spotlight the importance of interpretation (Frew, 2012; Gibb, 2006; Ham, 2007; Reisinger \& Steiner, 2006; Willis, 2009). Largely explained as an activity to make heritage places 'meaningful' to visitors (Hannam \& Knox, 2010:147; Moscardo, 1998), interpretation uncovers the meaning behind heritage emphasising its cultural, aesthetic and historical values (Goodey, 2006; Grimwade \& Carter, 2000). However, interpretation is also widely used as a tool for enhancing visitor experiences and transforming heritage sites into attractive tourist destinations (Gaffikin 2012; Ham, 2002; Io \& Hallo, 2011; Ward and Wilkinson, 2006).

Historic gardens are not an exception to this trend and their potential for attracting tourists has been recognised (Connell, 2005; Evans, 2001; Fox, 2007). Previous studies investigate visitor motivations (e.g. Connell \& Meyer, 2010; Lipovska, 2013). However, Connell (2005) argues that attention to interpretation and visitor experiences in historic gardens is required, whilst Poria, Biran \& Reichel (2009) call for further research capturing the impact of interpretation on visitor experiences.

This study addresses this gap in the literature by exploring the role of interpretation in historic gardens in the context of Wrest Park, a popular heritage garden site managed by English Heritage. Knowing and understanding the historic garden visitor who makes use of interpretation is key (Connell and Meyer, 2010). This paper seeks to explore how interpretation is used as tool for enhancing visitor experience and to evaluate its effectiveness in a historic garden context. Hence the key objectives of this study are to:

(i) uncover the type of audiences using interpretation methods in historic gardens;

(ii) investigate the role of interpretation on audience development vis-à-vis visitor perceptions of enhancing visitor learning experience in historic gardens;

(iii) define the extent to which interpretation methods in historic gardens can be seen as an effective and efficient tool in 'telling the story' - through facilitating learning, understanding and appreciation of the past - contributing to audience development

(iv) provide recommendations on how the range of interpretation methods may be improved.

The remainder of this paper is structured as follows: firstly, a discussion of prominent contributions from the extant literature on audience development and interpretation is provided alongside a snapshot of the current state of research into historic gardens; this is followed by a brief introduction to Wrest Park, English Heritage; the paper then outlines the 
methodology adopted to address the objectives of this study; the following section provides a discussion of the findings; the paper concludes with an extended discussion of the key findings, implications for theory and practice, and avenues for further research.

\section{Literature Review}

Interpretation methods reflect on a comprehensive set of information processing approaches (Ablett and Dyer, 2009) and are thus fundamental to developing audiences in heritage sites (Wolf, Stricker and Hagenloh, 2013). Yet, knowing and understanding the historic garden visitor who makes use of interpretation is just as important (Connell and Meyer, 2010) as individuals may be interested in different interpretive content (Poria, Biran and Reichel, 2009; Yankholmes \& Akyeampong, 2010). Not only do interpretation methods serve as an enabler for learning and understanding, but they also help shape the visitor experience through interpretation and hence deliver that story in a format that can be easily digested by the visitor.

Research indicates that a location i.e. a heritage site can be associated with a variety of meanings and memories (e.g. Moscardo, Ballantyne \& Hughes, 2007). Heritage sites in particular convey meanings by referring to specific historical attributes and other resources of the past through the use of interpretation - this transforms history and heritage into a language, which people can easily understand (Howard, 2003). A classic definition of interpretation is provided by Tilden $(1957$, p.8) who sees it as:

"an educational activity which aims to reveal meaning and relationships through the use of original objects, by first-hand experience, and by illustrative media, rather than simply to communicate factual information."

In the context of heritage, interpretation is an important tool for "making heritage places meaningful to visitors" (Hannam \& Knox: 147). According to the The Association for Heritage Interpretation, it is seen as a process of interaction that helps people make sense of, and understand more about historic sites, collections or events (Association for Heritage Interpretation, 2014). It is said to bring meaning to cultural or environmental resources, enhance the visitor appreciation and promote better understanding of the past having a fundamental impact on enhancing the visitor experience (Io \& Hallo, 2011; Timothy, 2011). Interpretation, as Moscardo (1998) contends, has an important role to play in contributing to the quality of visitor experience in three directions: information provision on the visitor offer; facilitating visitor safety and comfort when out and about; and importantly - creating the actual experience, learning and understanding. In line with this, Poria, Biren and Reichel (2009) argue that the contemporary role of interpretation goes well beyond meeting traditional objectives, such as enhancing knowledge and understanding, to evolve as a facilitator of emotional experience. Interpretation can and should be both informative and engaging (Frew, 2012). Interpretation allows for historical contextualising in its attempt to create meaningful experience (Barile, 2015). Gutic, Caie \& Clegg (2010) point out that 
interpretation has a vital function in unlocking the emotional-spiritual experience of visitors in historic sites.

Heritage interpretation is also the link between tourism and heritage - it transforms various attributes of the past as tourism products suitable for different target markets and audiences (Howard, 2003). Thus, interpretation is also a fundamental component of economic development of heritage sites (Uzzell, 1998). However, cultural, political and ideological roles of heritage are perhaps even more important than economic assets. How heritage is presented and interpreted, and the techniques used to construct the message to the audience both directly and indirectly - can have a significant impact over visitor experiences. Yet, as Poria, Biran \& Reichel (2009, p. 94) argue, "very few attempts have been made to evaluate interpretation quality or to clarify what constitutes good interpretation." Theoretical frameworks have been developed for enhancing visitor understanding and awareness of a historic site (e.g. see Porto, Leanza and Cascone, 2012), and embedding an authenticity dimension to heritage interpretation (Binoy, 2011). Yet, no frameworks or models have been developed to date in the area of audience development and enhancing the visitor experience through interpretation.

Further, Yankholmes \& Akyeampong (2010) contend that different visitors are interested in diverse aspects of interpretation at heritage sites. As a consequence, a plethora of interpretation methods have been developed in recent years (Rojas and Camarero, 2008) in an attempt to enhance the experience of visitors whilst visiting a heritage site and support learning and understanding in places of visitor interest. Guided tours, for example, have long been crucial to successful audience development as on site experts (i.e. tour guides) act as central agents between the visitor and the visited ( $\mathrm{Hu}$ and Wall, 2012). Also known as 'guided walks' (Bryant, 2006), the core strength of this interpretation technique is its face-toface nature of transferring knowledge. Tour guides have a crucial function to communicate site-specific information (Reisinger and Steiner, 2006) and thus contribute to better understanding of the heritage site (Porto, Leanza \& Cascone, 2012). Audio guides are another form of on-site interpretation. They are layered in stereo including narrative or commentary, along with background music and sound effects (Humphries, 2006). The latter effects, according to Willis (2009), add to the visitor experience as they build up a picture of what a site may have been like in the past. Increasingly appealing is the use of digital technologies (Taylor, 2006). Technological breakthroughs provide even more scope for interpretation (Bath, 2006). Interactive computer displays for example, allow visitors to control and choose the past that is best aligned with their interests (Poria, Biran and Reichel, 2009).

This study is, however, interested in a particular set of interpretation approaches and methods that are appealing to visitors in historic gardens. The extant research into historic gardens captures a number of discussions including: the preservation of historic gardens (Cheng \& Ma, 2009); the history and cultural values behind historic gardens (Roberts, 2007); historic gardens as heritage landscapes (Thompson, 1998); host and guest interaction ( $\mathrm{Su} \&$ Wall, 2014); sustainable planning and strategising for interpretation (Porto, Leanza \& Cascone, 2012); developing tourism, events and festivals (Benfield, 2013); approaches to conservation (Teasdale, 2015); horticulture management (Thoday, 2014); and promoting public awareness and historical value (Thani, Ibrahim, Mohamad \& Rodzi, 2015). 
Yet, Connell (2005) notes the lack of research into existing approaches to interpretation in historic gardens and their role with regards to audience development. The few contributions to this under-researched domain include Frew's (2012) discussion on dark tourism interpretation in a Tasmanian historic garden. Frew's (2012) contribution does not, however, enquire into how different tools and approaches to interpretation in historic gardens contribute to greater visitor understanding and thus shape audience development. This paper attempts to address this gap in the literature of heritage interpretation in historic gardens by enquiring into an English Heritage-owned and managed historic garden - namely Wrest Park.

\section{The context}

\subsection{The revitalisation project at Wrest Park}

Boasting over 90 acres of gardens and woodland, Wrest Park is one of the few places in the world where visitors can see the evolution of landscape gardening over the last 300 years. Wrest Park's gardens are full of history: the baroque Archer Pavilion and Chinese Temple, and the $18^{\text {th }}$ century Bowling Green House - along with over 40 statues dotted around the gardens (English Heritage, 2014a) - add value and authenticity to the visitor experience. The Wrest Park estate - part of a Grade One Registered Park of exceptional interest (English Heritage, 2012c; Charlesworth, 2012) - evolved under the ownership of the de Grey family from the 14th century until the early 20th century (English Heritage, 2012a). In 2006, English Heritage gained ownership of this unique site located near the small village of Silsoe, Bedfordshire. Over the years, the formal gardens have been lost or simplified to make them easier to maintain. With support from the Heritage Lottery Fund (Lambert and Lovie, 2014) and the John Paul Getty Jnr Charitable Trust, English Heritage recently returned the gardens at Wrest Park to the designs introduced under the de Grey family, complemented by work done by Capability Brown.

English Heritage is the government's principal advisor on historic environments (Hems, 2006). Acting as the custodian of Wrest Park, English Heritage launched the 2010 Revitalisation Project to return the gardens to their original appearance, restoring the Rose Garden, American Garden, Italian Garden, woodlands, and French Parterre with vibrant and colourful new planting schemes. With continued support, English Heritage plans to move forward with a 20-year plan which will see restoration work commissioned in the Great Garden and Ladies Lake (English Heritage, 2012a). With the help of the Art Fund, the statue of Diana, lost to Wrest in the early 20th century, was recently bought back and placed in its original spot at the head of Ladies Lake. Funding also provided Wrest Park with the opportunity to hire four garden apprentices and organise outreach work to engage the local community with their heritage.

In 2011, the project also saw the introduction of new visitor facilities and new interpretation in the Mansion House and gardens. The restoration of the Rose Garden and the Italian Garden were also completed. The French Parterre was restored in 2012 and a new sculpture gallery opened allowing visitors to see the story of gardening in England across three centuries. Wrest Park uses a range of interpretation methods to enhance visitor 
knowledge and understanding of the site, namely audio guides, children's trails, interactives, guided tours and exhibition.

In addition, Wrest Park hosts a number of events during the summer months. Prominent events include Victorian Delights, Music on a Sunday Afternoon and Heroes \& Highwaymen (English Heritage, 2014b). Events include family day-out activities, along with history-centric events where visitors get to see more of Wrest Park's past through live interpretation. Following these recent developments, an Audience Development Manager was recruited to undertake a series of projects with the local community to help understand Wrest Park audiences better (English Heritage, 2012b). Wrest Park have been developing new ways in which people can learn, enjoy and get involved with its historic gardens and this paper aims to shed light on how history is unfolding in this unusual English Heritage site.

Within the context of the above set of interpretation methods, Wrest Park's historic gardens, building and other key physical areas of the heritage site have been utilised for the purpose of gathering visitor feedback.

\section{Methods}

\subsection{Sample}

In investigating the impact of interpretation on the learning and understanding of Wrest Park visitors while providing a background to audience profiles, the research utlised short, semistructured interviews aimed at visitors in situ. The study sample draws on individual visitors $(n=65)$ who have experienced a range of storytelling techniques and visitor interpretation methods at the time of their visit to Wrest Park. A qualitative technique involving semistructured interviews was chosen with a view to gaining deeper insights into the visitors' experiences of the interpretation methods on site. Adopting a merely quantitative approach would have resulted in predominantly descriptive data with little insight into the experiences of individual visitors.

The interviews (refer to Appendix 1 for a survey questionnaire) took place on site over two consecutive weeks in July 2012. The research team adopted a blend of nonprobability, also called judgemental sampling techniques (see Bryman \& Bell, 2011), namely purposive and quota (see Bryman, 2012) when potential study participants were approached. A purposive sampling technique was first employed in order to capture the profiles of individuals visiting Wrest Park during weekends, along with those visiting during week days. Both users and non-users of interpretation methods were approached at the time of conducting the interviews. In approaching these two groups, the research team drew on quota sampling with a target of a minimum of 60 interviews serving to explore contrasting perspectives of visitor experiences of Wrest Park's interpretation methods, their popularity, and perceived efficiency in telling the story of the place. Approximately $20 \%$ of the approached 80 individuals declined to be involved, which resulted in the achieved sample of $\mathrm{n}=65$. 
A significant proportion of the visitors were using the interpretation methods at the time of data collection. Interviews with visitors commenced at a time when they were not engaged in using interpretation in an attempt to limit the potential negative impact on the visitors' experience.

\subsection{Data analysis}

The interviews were transcribed verbatim (Hennink, Hutter and Bailey, 2011) and the resulting 'thick', yet largely raw data were utilised as an input into NVivo10 (QSR International, 2013). The tool is practical in terms of organising large amounts of qualitative data and the development of consistent coding schemes (Jennings, 2010). The resultant largely 'thick' data have been analysed through the development of a hierarchical structure of themed nodes in line with the adopted survey questionnaire (see Appendix 1). This process was followed by coding interview data under each themed node with the intention to reveal emerging themes corresponding to the range of interpretation methods provided on site. Emerging themes then informed and ultimately shaped the discussion of findings stemming from this research. This procedure was followed by further thematic analysis (Bryman, 2012) of the nodes, which reflect the project objectives.

Further to the above, a word frequency analysis was conducted (Bazeley and Jackson, 2013) through NVivo10's built in word cloud tool drawing on nodes capturing individual visitor reflections with regards to the set of interpretation methods. This analysis reveals the most common words and phrases highlighted by respondents when sharing their personal experience of using individual interpretation methods. The 20 most popular words among visitors, which are $>=4$ characters have been considered for inclusion in the analysis. Hence words having characters less than 4 have been omitted from this study.

\section{Findings and discussion}

Prior to exploring the role of interpretation methods in enhancing the learning experience of visitors in historic gardens, this paper provides context to the adopted sample through exploring the profile of individuals interested in this specific type of heritage tourism.

\subsection{Visitor profiles}

Of the 65 interviews that were carried out, 22 covered young families whereas the other 43 involved senior visitors of Wrest Park. The former captured the majority of Wrest Park's weekend visitors while the latter were the dominant visitor group during weekdays. In its approach to identifying visitor profiles, this study has adopted Chen's (1998) classification of heritage visitors. The two key motives for visiting Wrest Park included the pursuit of knowledge (e.g. understanding and appreciation of the past) and personal benefit (e.g. relaxation and recreation). The former group are labeled as history explorers, and the latter: 
outdoor leisure seekers building on Chen's (1998) classification of heritage visitors. The majority of the sample comprises outdoor leisure seekers which accounts for $57 \%$ of the visitors (see Figure 1).

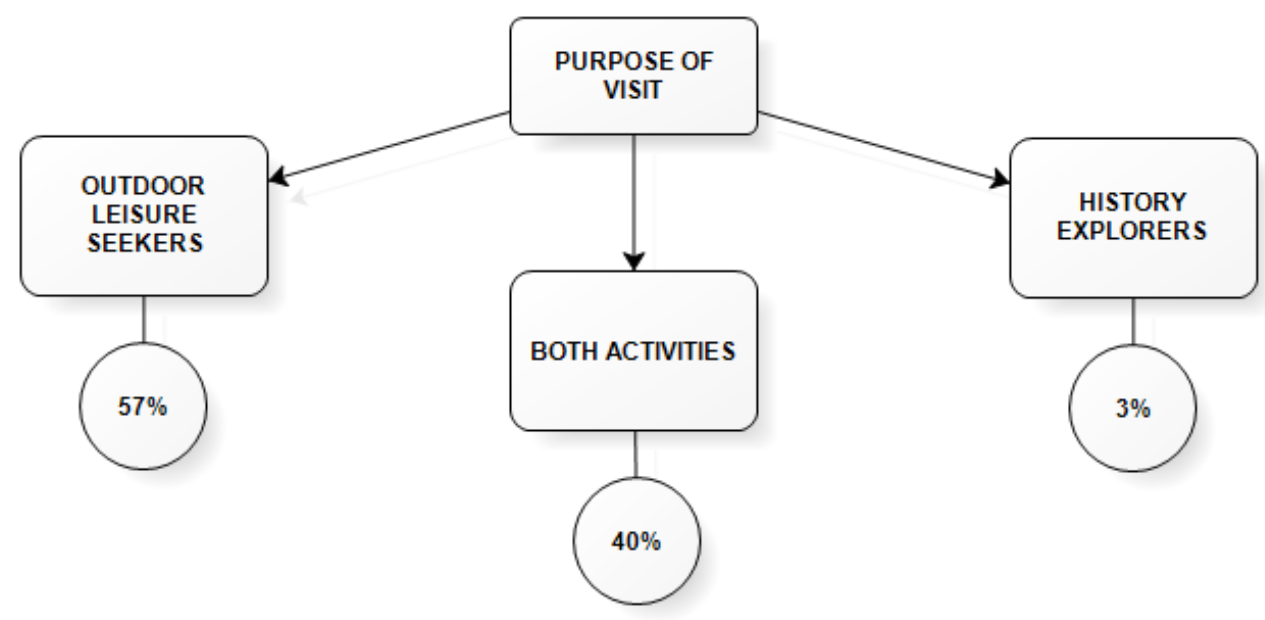

Figure 1. Purpose of Visiting Wrest Park

This does not come as a surprise since nearly a decade ago Connell (2005) discussed the changing role of historic gardens now seen as a leisure resource. The historic gardens, along with the children's play area were key pull factors for this dominant visitor group. On the contrary, pure history explorers comprised just over $3 \%$ of the sample. Findings nevertheless point to a third, hybrid group, which account for $40 \%$ of the sample and encompass visitors who were not just interested in exploring Wrest Park's gardens, but also the history, evolution and significance of the place.

Further, the ratio of first time versus repeat visitors reveals the extent to which historic gardens with interpretation methods on-site generate repeat interest. The majority of Wrest Park visitors were first timers and thus accounting for 55\% of the sample. Repeat visitors (45\%) included individuals who were interested in Wrest Park's Revitalisation Project and its further development as a heritage site. A significant proportion of Wrest Park's repeat visitors (14\%) were from the local community, mainly Silsoe and surrounding villages in Central Bedfordshire. Further, members of heritage organisations contributed to $48 \%$ of Wrest Park's visitor sample - of which $45 \%$ were members of English Heritage and a further 3\% were members of the National Trust. Finally, the proportion of approached visitors using each interpretation method provided on-site was identified prior to exploring their learning experience at Wrest Park. The outcomes highlighted the popularity of individual interpretation methods provided to Wrest Park visitors. 


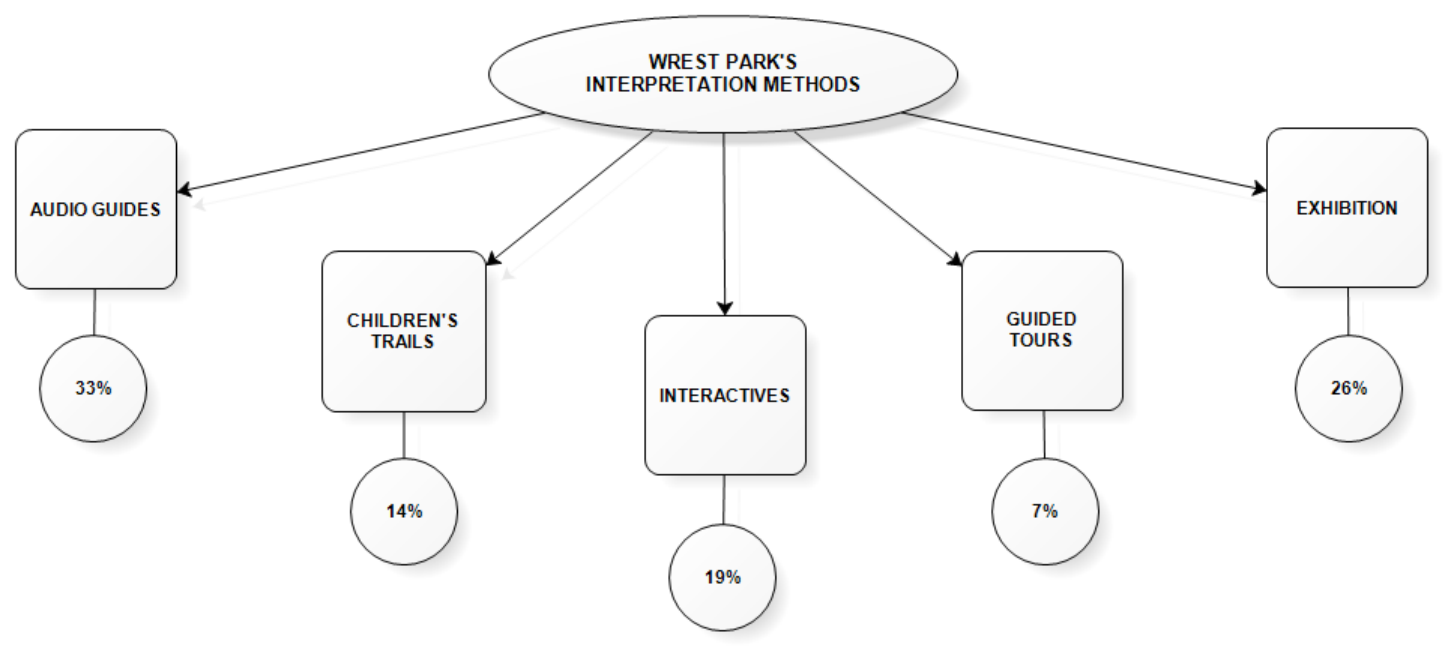

Figure 2. Popularity of Wrest Park's Interpretation Methods

The Audio Guides and Exhibition accounted for nearly $60 \%$ of the total use of interpretation methods as illustrated on Figure 2 above. The Children's Trails and Interactives have been experienced by a third (33\%) of the sample. In contrast, the relative share of the Guided Tours amongst Wrest Park visitors was just over 7\%.

\subsection{Surfacing the learning experience of visitors through interpretation}

In line with the literature on interpretation methods adopted in historic gardens, this section of the paper provides a set of self-explanatory depictions to reflect the overall experience of visitors when using each of the five interpretation methods provided in Wrest Park. In other words, this section discusses the outcomes of the word frequency analysis discussed in the methods section.

\subsubsection{Audio guides}

As self-guided audio interpretation aids, audio guides are being used - in parallel with a map to guide visitors across key historic garden spots. Audio guides have been experienced by $33 \%$ of the sample and appear to be the most prominent form of interpretation - particularly amongst seniors - when exploring the Park's history. Unlike other interpretation methods, with 33\% audio guides were "fantastic" and frequently used tool in Wrest Park as reported by seniors.

All interviewed participants who experienced the audio guides found them to be very informative, comprehensive and helpful since they provided a detailed account of Wrest Park's history (Figure 3). The guides provided a convenient learning aid to visitors, as some felt more comfortable with interpretation that requires listening in contrast to reading.

Senior interviewees pointed out that the guides were "user friendly", making them easy to operate. The audio guides were repeatedly considered as being "an outstanding tool of interpretation" which is widely experienced in the Park. 


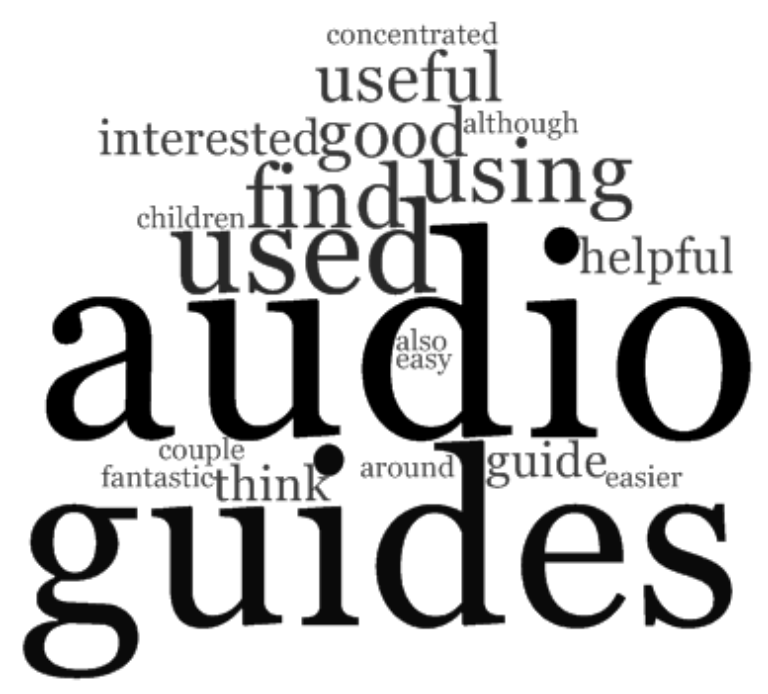

Figure 3. Audio Guides: Visitor Impressions

Young families on the contrary, seemed to have difficulties when using audio guides as children barely expressed consistent interest in such interpretation methods. Wrest Park's youngest visitors were rather focused on activities associated with the children's play area. Despite parents seeing guides to be "very useful," when accompanied by children, their interest in using audio guides was generally low.

\subsubsection{Children's trails}

Children's Trails were another interpretation technique adopted in Wrest Park in an attempt to respond to the challenge of engaging all family members in the story of Wrest Park. English Heritage (2014c) advocates the use of children's interpretation as a medium to engagement and improving learning and appreciation outcomes. The Wrest Park chilren's trails comprise a set of quizzes, along with audio equipment allowing children to learn and explore as they play. This method was experienced by $14 \%$ of the sample as depicted on Figure 4 below.

Further, analysis of the data reveals that only six out of the 22 families interviewed reported that they had used the children's trails. Indeed, one of the families suggested that "the promotion of such activities within the park is poor" saying that they did not know about the children's trails until they were mentioned by the research team. Families who experienced the children's trails were nevertheless positive about the method pointing out that "they are very good and their children enjoyed them." 


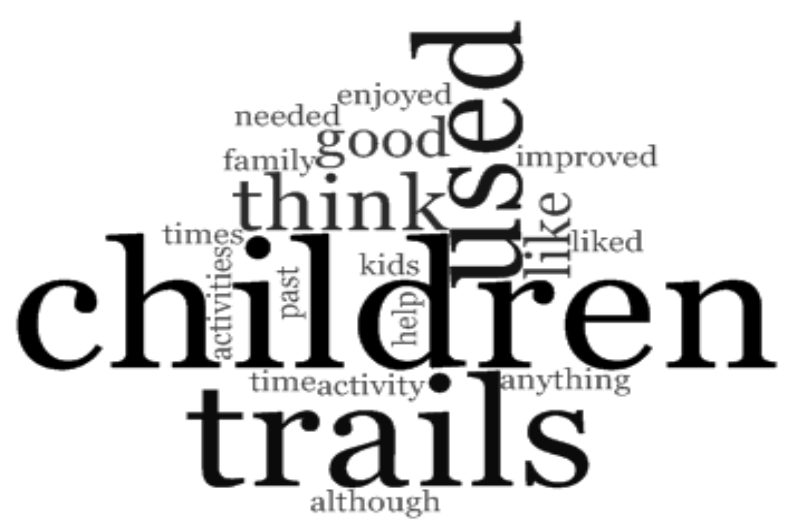

Figure 4. Audio Guides: Visitor Impressions

Though the youngest visitors 'needed help', children loved doing the trails. Some children were even repeat visitors. Parents meanwhile noted that the children's trails are most frequently used during the school holidays.

\subsubsection{Interactives}

Interactives at Wrest Park is where technology meets history. A set of user-guided screens and other multimedia are used to create an interactive experience of key moments of Wrest Park's past. The interactives were experienced by $19 \%$ of the sample, and appear to be both informative and well presented (Figure 5). Interviewees pointed out that they are a practical means of telling the "story of the family who lived in the Mansion House and the overall significance of Wrest Park." Indeed, the interactives provide a comprehensive account of Wrest Park's past and aid with understanding of history, as suggested by one family: "this sort of interactives where you actually get involved with the history of the place, walk around and get to see the whole house make you understand a bit more about it."

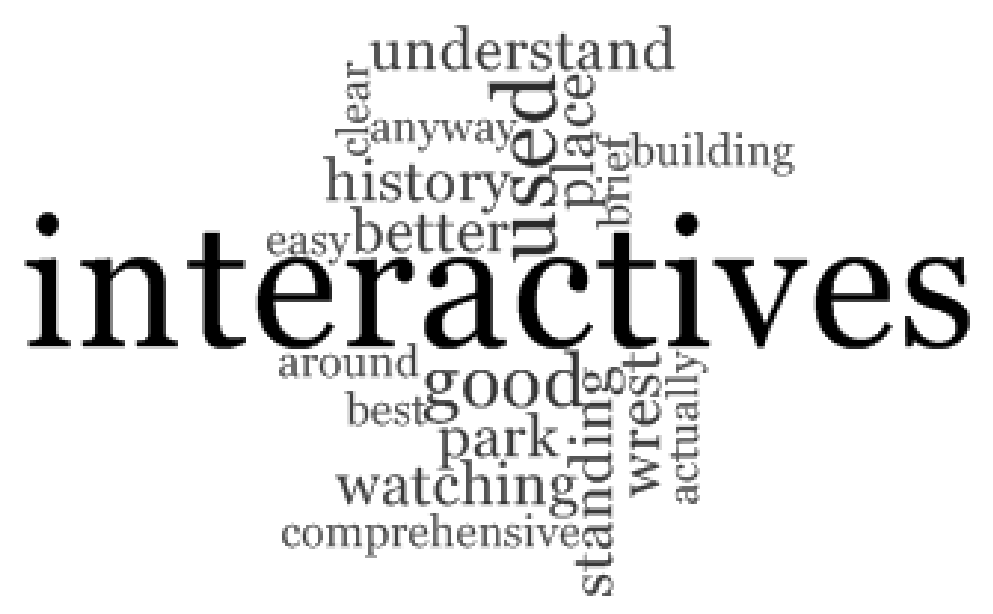

Figure 5. Interactives: Visitor Impressions

Popular among both families and seniors, a key advantage of this interpretation method was its ability to actively engage the audience and - as pointed out by one of the senior visitors - 
"take visitors back in centuries to the time of the Park's active existence". Interactives increased visitor understanding of the place and played an important role in enhancing visitor knowledge about Wrest Park.

Some of the sampled visitors preferred short presentations as "there is a lot more to be seen" which requires additional time. For others, it was important to be constantly involved in different interactive activities pointing to the key role of interactives in creating an engaging storytelling of a place.

\subsubsection{Guided Tours}

Guided Tours were another popular interpretation approach among seniors. Taking guided tours around the gardens was an alternative option to audio guides to appreciate the scale, significance and history of Wrest Park's historic gardens. Drawing on the achieved sample of Wrest Park visitors, families did not express any interest in this interpretation method. Despite the relatively small number of sampled visitors making use of guided tours (7\%), the overall experience of being led by someone with vast knowledge of Wrest Park was beneficial to "enforcing learning and understanding" as pointed out by a senior visitor.

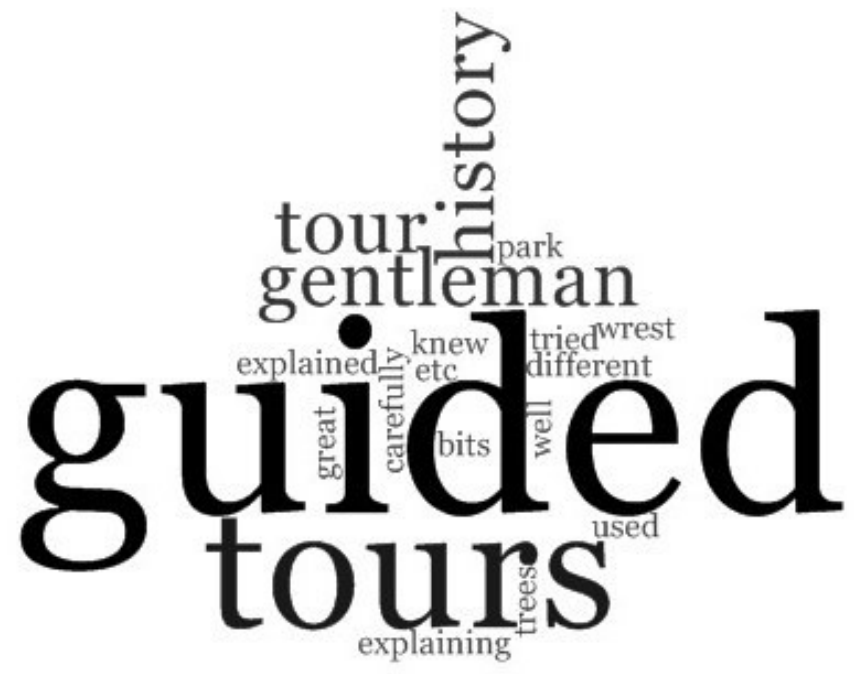

Figure 6. Guided Tours: Visitor Impressions

Interviewees found guides to be very professional and knowledgeable when unfolding Wrest Park's history. Guides provided "an engaging discussion on the buildings, gardens and trees" being present in the Park (Figure 6). The extent to which guided tours responded to visitor expectations was considered as high, mainly due to the "very detailed and comprehensive information" provided by the staff in charge of the tours.

\subsubsection{Exhibition}

With $26 \%$ of the sample reporting to have experienced the exhibition, it proved to be another relatively popular interpretation method across Wrest Park visitors. The exhibition enabled 
visitors to see the story of the estate and the de Grey family who lived there for over 600 years. The exhibition was equally popular among both families and seniors. The majority of participants who attended the exhibition agreed that it met their expectations of a history experience (Figure 7). Indeed, the exhibition was considered to be "very interesting, comprehensive and well-structured". It thus seems that the exhibition was engaging and informative.

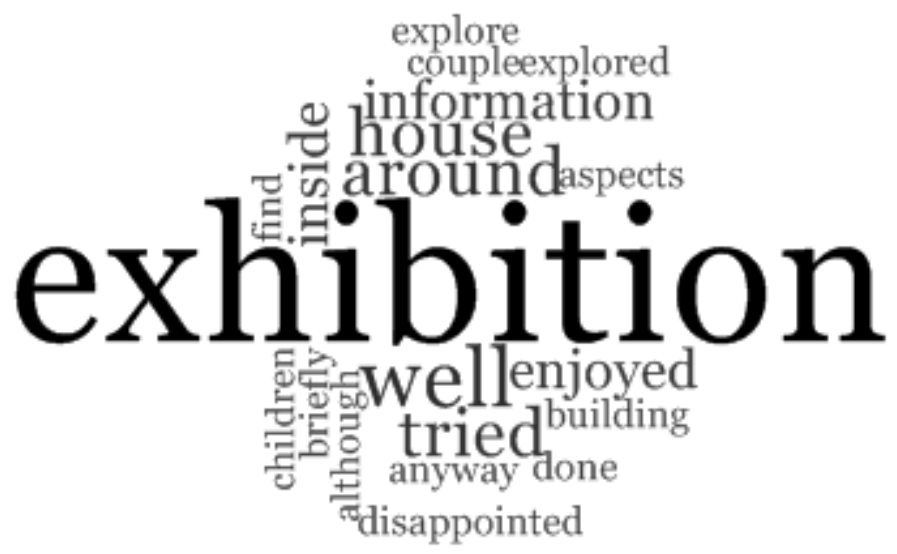

Figure 7. Exhibition: Visitor Impressions

A senior couple highlighted that "the amount of the information provided is very intense" and hence, "individuals who are history explorers should be visiting Wrest Park repeatedly" in order to be familiar with the history of this historic garden. Other sampled visitors were keen on exploring a larger number of rooms, along with the top floor of the Mansion House though only part of it was open to visitors due to the Revitalisation project taking place at the time.

This section explored the range of interpretation methods at Wrest Park and their impact on audience development from a qualitative perspective. Building on these insights, the study also highlights the quantitative dimension of how successful the range of interpretation methods were at telling the story of Wrest Park. Findings across the achieved sample reveal that $92.5 \%$ of these visitors understand some elements of Wrest Park's history, significance and evolution through making use of interpretation methods. They reported three key areas of knowledge gained through interpretation, namely the transformation of Wrest Park throughout the centuries, the history of the de Grey family, and a detailed retrospective account of the evolution of Wrest Park's gardens.

\section{Recommendations and conclusion}

The rationale behind this study was to investigate the range of interpretation methods available in historic gardens, the audiences making use of them, and the impact of these storytelling techniques on enhancing visitor understanding, learning and audience development in general. The findings draw on an investigation in situ i.e. Wrest Park, English Heritage. 


\subsection{Recommendations for historic garden practitioners}

The empirical work reported in this paper provides evidence that the overall performance and popularity of Wrest Park's interpretation methods among visitors was relatively high resulting in a high degree of visitor interaction with Wrest Park's exhibit elements. An emphasis should, nevertheless, be placed on raising the awareness of visitors on the range of interpretation methods available to them - particularly families. As this paper discussed, the number of history explorers in Wrest Park was generally low accounting for 3\% of the sampled visitors. Hence, the venue should work towards attracting more individuals keen on history and widening participation may well be achieved through improving the 'visibility' of interpretation available to visitors. The promotion of the provided interpretation methods is equally important to both senior visitors and families in historic gardens. Although interpretation methods are generally popular among seniors as the analysed data reveals, efforts should be pointed towards targeting more individuals and families alike. In contrast to families, senior visitors were more likely to engage and participate in history-centric activities when using Wrest Park's interpretation methods. Others expressed interest in learning more about Wrest Park's history, despite not being keen on the current set of interpretation methods provided. This is where interpretation through historic events linked to the history of the place can encourage learning and understanding.

This paper began with the idea that taking on board visitor preferences for on-site interpretation is fundamental to the management of heritage attractions (Poria, Biran and Reichel, 2009) and audience development. Hence in addressing historic garden practitioners, this section of the paper discusses key insights derived from the sample of visitors and the (emic) position of the researchers in light of improving the existing interpretation offering in Wrest Park.

In general, the above discussion suggests that visitors of Wrest Park had a positive attitude towards the value of using audio guides in historic gardens. It would, nevertheless, be good if they involved relevant music as a background, which may complement the overall experience of the historic narrative as some of the participants highlighted this as a point of improvement. The audio guides can thus become more engaging and exciting - they can contribute towards a more immersive experience for visitors in historic gardens. Audio guides were not genuinely considered as an option to families who are more interested in interpretation methods involving games. Storytellers could therefore be contracted to create children's narratives that incorporate play.

Children's trails can also be improved by becoming more accessible with content tailored for younger children. In line with this, Macklin, Hvenegaard and Johnson (2010) argue that the field needs new approaches to interpretation to better address children's enjoyment and learning in heritage sites. English Heritage (2014c) argues that contemporary interpretation for children should be aligned with curriculum whatever the tool or approach to interpretation. In this case, experiences designed for children of different age groups would be an advantage for this interpretation method. Indeed, Wrest Park should focus on more 
activities for children in terms of interpretation methods according to families visiting the venue.

Despite being largely successful, interactives can also be improved by providing more detailed information related to other people who lived in the Mansion House in addition to the de Gray family. Wrest Park and other historic gardens using interactives can enhance the visitor experience by adding more relevant information which may be appealing to history explorers - a group that clearly needs to be expanded as the above discussion suggests.

Though the Guided Tours were relatively well received by visitors, some individuals would prefer the tour guide to provide more detailed explanation including horticultural information. The latter places emphasis on the importance of live interpreters, which as Tabraham (2006) has argued, is the most successful vehicle for communicating the message of a place.

In terms of the exhibition provided in Wrest Park, visitors would like to be able to see more details of the Mansion House, particularly the upper floor of the house. Taking a step forward, an option would be the provision of furniture in some of the halls as visitors highlighted. Curiosity of history explorers in heritage gardens therefore can be seen as an opportunity for historic gardens to explore further opportunities in fully providing the story of a place.

Engaging with audiences in historic gardens is of key importance to understanding visitors. Arguably, using interpretation as a means of achieving greater understanding of the past and significance of historic gardens is important to those consuming the heritage. Understanding audiences may well be seen as key to this process and the role of historic garden practitioners in responding to visitor needs should not be underestimated.

\subsection{Implications for theory and practice}

This study provided insights into a range of interpretation methods experienced by visitors of historic gardens and visitor typologies (audiences) who make use of them. Within the context of the last section and in an attempt to support the case of events used in historic gardens, a recent UNESCO (2013) discussion suggests that heritage should be seen as more than a representation of the medieval architecture and historic buildings (UNESCO, 2013). Heritage and indeed, historic gardens should not be regarded as static, out of context (Hewison, 1987) places. Historic gardens' physical dimension should be supplemented by the hidden cultural traits and qualities of a place, often expressed through events and festivals, traditional arts and crafts, music and literature. Likewise, Saxe (2009) proposed the application of a living heritage - one that improves visitor experience by mixing heritage with entertainment. Robertshaw (2006) builds on the concept of living heritage by arguing for the importance of 'live interpretation'. The latter involves people - usually costumed and in a historic setting who place artefacts, places or events in context against the background of the human environment of the past (Robertshaw, 2006).

Enriching the visitor experience through a sustainable (English Heritage, 2008), yet innovative and engaging approach to heritage management where physical heritage meets 
live interpretation of site-specific historic accounts enhances learning and understanding of the past. Along with family day-out experiences, events based around the history of a place can act as a pull factor for those who are keen on exploring the past. Local communities can be part of this agenda (Bryant, 2006).

Further, the paper provides a basic typology of key audiences in historic gardens, which is based on a single case. Knowing one's audience is undoubtedly key to enhancing the visitor experience, along with creating and sustaining long-term relationships. Other historic gardens with similar characteristics and interpretation tools on offer may be able to use the findings from this study to tailor their provision of interpretation for audience development purposes and enhancing the visitor experience.

\subsection{Study limitations and future research avenues}

The role of interpretation in enhancing the visitor experience has been widely acknowledged (Ham, 2007). However, the literature on interpretation in historic gardens is scarce (Connell and Meyer, 2010) and thus more evidence of how interpretive approaches support visitor learning and understanding in historic gardens is needed. The transactions that occur between historic sites, interpreters and visitors (Copeland, 2006) therefore deserve further attention.

The outset of this paper highlighted the nature of the underpinning research as being one that provides initial insights into the use of interpretation in historic gardens. Hence the present study has several limitations.

From a methodological perspective, this study provides limited insights as it draws on a single case study and a limited number of interviews on situ due to restrictions to visiting the site for research purposes. Hence, further, more in depth research into English Heritage historic gardens and those beyond the garden portfolio of English Heritage is needed. Furthermore, the limited sample in this study makes it hard to generalise about visitor preferences of adopted interpretation methods. This limitation can be addressed through the use of a larger quantitative sample of visitors and users of interpretation methods in historic gardens. The latter is therefore another avenue of future research and thus deserves further attention. Further research into the hybrid group (history explorers + outdoor leisure seekers) is also needed. Finally, this study provides limited insights with regards to audience development and interpretation in historic gardens. This limitation is rooted in the limited evidence to date on the topic and the lack of theoretical frameworks developed in the context of historic gardens. Consequently, the field would benefit from further research into developing a framework for audience development through interpretation in historic gardens, where the interplay with existing theoretical concepts from the wider interpretation literature is just one example of this avenue.

Within this context, this study calls for more evidence of empirical research in the context of historic gardens, where interpretation is adopted as a pivotal approach to audience development and improving the visitor experience. 


\section{References}

Ablett, P. G. and Dyer, P. K. (2009) Heritage and Hermeneutics: Towards a Broader Interpretation of Interpretation, Current Issues in Tourism, 12 (3), pp.209-233

Arts Council England (2011) Grants for the Arts: Audience Development and Marketing, Manchester: Arts Council England

Association for Heritage Interpretation (2014) What is Interpretation?, Available at: http://www.ahi.org.uk/www/about/what_is_interpretation/(Accessed 1 June 2014).

Barile, S. (2015) Towards a Novel Conception of Bene Culturale, in Golineli, G. M. (eds) Cultural Heritage and Value Creation: Towards New Pathways, London: Springer, pp. $53-71$

Bath, B. (2006) The Use of New Technology in the Interpretation of Historic Landscapes, in Hems, A. and Blockley, M. (eds.) Heritage Interpretation, London: Routledge, English Heritage, pp.163-173

Bazeley, P. and Jackson, K. (2013) Qualitative Data Analysis with NVivo $2^{\text {nd }}$ edn. London: SAGE

Benfield, R. (2013). Garden tourism. London: CABI.

Binoy, T. A. (2011). Archaeological and heritage tourism interpretation. A study. South Asian Journal of Tourism and Heritage, 4(1), 100-105.

Bryant, M. (2006) Tilden's Children: Interpretation in England's National Parks, in Hems, A. and Blockley, M. (eds.) Heritage Interpretation, London: Routledge, English Heritage, pp.173-189

Bryman, A. and Bell, E. (2011) Business Research Methods $3^{\text {rd }}$ edn. Oxford: Oxford University Press.

Bryman, A. (2012) Social Research Methods $4^{\text {th }}$ edn. Oxford: Oxford University Press.

Chen, J. S. (1998) Travel Motivation of Heritage Tourists, Tourism Analysis, 2 (3-4), pp.21315.

Cheng, M., Jin, X. and Wong, I. A. (2014) Ecotourism Site in Relation to Tourist Attitude and Further Behavioural Changes, Current Issues in Tourism, 17 (4), pp.303-311

Cheng, E. W., \& Ma, S. Y. (2009). Heritage conservation through private donation: the case of Dragon Garden in Hong Kong. International Journal of Heritage Studies, 15(6), 511-528.

Connell, J. (2002). A Critical Analysis Of Gardens as a Resource for Tourism and Recreation in the UK. Unpublished doctoral dissertation, University of Plymouth, Plymouth, United Kingdom.

Connell, J. (2005) Managing gardens for visitors in Great Britain: A story of continuitymand change. Tourism Management, 26, 185-201.

Connell, J. and Meyer, D. (2010) Modelling the Visitor Experience in the Gardens of Great Britain, Current Issues in Tourism, 7 (3), pp.183-216

Copeland, T. (2006) Constructing Pasts: Interpreting the Historic Environment, in Hems, A. and Blockley, M. (eds.) Heritage Interpretation, London: Routledge, English Heritage, pp.83-97

Charlesworth, M. (2012) England's Historic Gardens, The Journal of Garden History, 10 (4), 


\section{pp.252-253}

English Heritage (2008) Conservation Principles, Policies and Guidance: For The Sustainable Management of the Historic Environment. London: English Heritage.

English Heritage (2012a) The Revitalisation Project at Wrest Park. Available at: http://www.english-heritage.org.uk/daysout/properties/wrest-park/our-plans/

(Accessed 30 May 2014).

English Heritage (2012b) Developing New Audiences at Wrest Park. Available at: http://www.english-heritage.org.uk/daysout/properties/wrest-park/our-plans/audiencedevelopment/ (Accessed 30 May 2014).

English Heritage (2012c) Designation Scheduling Selection Guide: Gardens, London: English Heritage.

English Heritage (2014a) Wrest Park: Step Into England's Story, London: English Heritage

English Heritage (2014b) Events at Wrest Park, Available at http://www.englishheritage.org.uk/daysout/properties/wrest-park/events (Accessed 1 June 2014).

English Heritage (2014c) Conservation: Children and Place

Evans, M. (2001) Gardens tourism - Is the market really blooming? Insights, 12, pp.153159.

Fox, D. (2007) Understanding garden visitors: The affordances of a leisure environment. Unpublished doctoral dissertation, Bournemouth University, Dorset, United Kingdom.

Frew, E. A. (2012). Interpretation of a sensitive heritage site: the Port Arthur Memorial Garden, Tasmania. International Journal of Heritage Studies, 18(1), 33-48.

Gallaher, J. (1983) Visiting historic gardens. A report on contemporary garden visiting and its literature. Leeds: Leeds Polytechnic.

Gaffikin, A. (2012) Creating a Whole New Visitor Experience Approach at Kensington Palace, Gillingham: Association for Heritage Interpretation

Gibb, R. (2006) Highland Interpretive Strategy Project, in Hems, A. and Blockley, M. (eds.) Heritage Interpretation, London: Routledge, English Heritage, pp.33-41

Goodey, B. (2006) Interpreting Urban Heritage in Hems, A. and Blockley, M. (eds.) Heritage Interpretation, London: Routledge, English Heritage, pp.9-33

Grimwade, G. and Carter, B. (2000) Managing Small Heritage Sites with Interpretation and Community Involvement, International Journal of Heritage Studies, 6 (1), pp.33-48

Gutic, J., Caie, E., \& Clegg, A. (2010). In search of heterotopia? Motivations of visitors to an English cathedral. International Journal of Tourism Research, 12(6), 750-760.

Halbrooks, M. C. (2005) The English Garden at Stan Hywet Hall and Gardens: Interpretation, Analysis, and Documentation of a Historic Garden Restoration, HortTechnology, 15 (2), pp.196-213

Humphries, P. (2006) Heritage Interpretation and CADW, in Hems, A. and Blockley, M. (eds.) Heritage Interpretation, London: Routledge, English Heritage, pp.71-83

Ham, S. (2002) Meaning making and interpretation in the Tasmanian tourism industry. Keynote address to the Tasmanian Conference on the Theory and Practice of Interpretation in Tourism, University of Tasmania, Hobart, 2002

Ham, S (2007) Isolating the Role of On-site Interpretation in a Satisfying Experience, Journal of Interpretation Research, 12 (2), pp.5-25 
Hems, A. (2006) Thinking about Interpretation: Changing Perspectives at English Heritage, in Hems, A. and Blockley, M. (eds.) Heritage Interpretation, London: Routledge, English Heritage, pp.189-201

Hennink, M., Hutter, I. and Bailey, A. (2011) Qualitative Research Methods, London: SAGE. Hewison, R. (1987) The Heritage Industry. London: Methuen

Howard, P. (2003). Heritage: management, interpretation, identity. A\&C Black.

$\mathrm{Hu}$, W. and Wall, G. (2012) Interpretive Guiding and Sustainable Development: A Framework, Tourism Management Perspectives, 4, pp.80-85

Io, M. and Hallo, L. (2011) Tour Guides' Interpretation of the Historic Centre of Macao as a World Cultural Heritage Site, Journal of Tourism and Cultural Change, 9 (2), 140152

ICOMOS (1982) Historic Gardens (The Florence Charter 1981). Available at: https://www.icomos.org/images/DOCUMENTS/Charters/gardens_e.pdf. Accessed on 14/07/2017.

Jennings, G. (2010). Tourism Research. Brisbane: John Wiley.

Lambert, D. and Lovie, J. (2014) All Rosy in the Garden? The Protection of Historic Parks and Gardens, Journal of Architectural Conservation, 12 (3), pp.83-106

Laurie, I. C. (2007) Surveys of Historic Parks and Gardens, Planning Outlook, 26 (2), pp.8998

Lipovska, B. (2013) The Fruit of Garden Tourism May Fall Over the Wall: Small Private Gardens and Tourism, Tourism Management Perspectives, 6, pp.114-121

Macklin, E. K., Hvenegaard, G. T. and Johnson, P. E. (2010) Improvisational Theatre Games for Children in Park Interpretation, Journal of Interpretation Research, 15 (1), pp.715

Mawrey, G. and Groves, L. (2010) The Gardens of English Heritage, London: Frances Lincoln.

Moscardo, G. (1998) Interpretation and sustainable tourism: Functions, examples and principles. Journal of Tourism Studies 9 (1), 2-13.

Moscardo, G., Ballantyne, R. \& Hughes, K. (2007). Designing Interpretive Signs: Principles in Practice. Golden, CO: Fulcrum Publishing

Naumov, N. (2015) Heritage and tourism: Reconceptualization of the past as an experience. Journal of Tourism \& Services 11, 83-88.

Poria, Y., Biran, A. and Reichel, A. (2009) Visitors' Preferences for Interpretation at Heritage Sites, Journal of Travel Research, 48 (1), pp.92-105.

Porto, S., Leanza, P. M., \& Cascone, G. (2012). Developing interpretation plans to promote traditional rural buildings as built heritage attractions. International Journal of Tourism Research, 14(5), 421-436.

QSR International (2013) Products: NVivo10, Available at: http://www.qsrinternational.com/products_nvivo.aspx (Accessed 16 February 2014).

Reisinger, Y., and Steiner, C. (2006) Reconceptualising interpretation: The role of tour guides in authentic tourism. Current Issues in Tourism, 9(6), pp.481-498.

Roberts, J. (2007). The gardens of Dunroamin: History and cultural values with specific reference to the gardens of the inter-war semi1. International Journal of Heritage 
Studies, 1(4), 229-237.

Robertshaw, A. (2006) Live Interpretation, in Hems, A. and Blockley, M. (eds.) Heritage Interpretation, London: Routledge, English Heritage, pp.41-55.

Rojas, C.D., \& Camarero, C. (2008) Visitors' experience, mood and satisfaction in a heritage context: Evidence from an interpretation centre. Tourism Management, 29, 525-537.

Saxe, D. W. (2009) An Experimental Model Mixing Heritage and Entertainment, Journal of Interpretation Research, 14 (1), pp.33-47

Su, M. M., \& Wall, G. (2014). Exploring the Shared Use of World Heritage Sites: Residents and Domestic Tourists' Use and Perceptions of the Summer Palace in Beijing. International Journal of Tourism Research.

Tabraham, C. (2006) Interpreting Historic Scotland, in Hems, A. and Blockley, M. (eds.) Heritage Interpretation, London: Routledge, English Heritage, pp.55-71

Taylor, R. (2006) The National Trust, in Hems, A. and Blockley, M. (eds.) Heritage Interpretation, London: Routledge, English Heritage, pp.97-111

Teasdale, J. (2015). Gardens and landscapes in historic building conservation. Journal of Architectural Conservation, (ahead-of-print), 1-2.

Thani, S. K. S. O., Ibrahim, N. K., Mohamad, N. H. N., \& Rodzi, N. I. M. (2015). Public Awareness towards Conservation of English Landscape at Taiping Lake Garden, Malaysia. Procedia-Social and Behavioral Sciences, 168, 181-190.

Tilden, F. (1957) Interpreting Our Heritage, North Carolina: University of North Carolina Press.

Timothy, D. J. (2011) Cultural Heritage and Tourism: An Introduction, Bristol: Channel View Publications

Thoday, P. (2014). Science and craft in understanding historic gardens and their management. Gardens \& Landscapes in Historic Building Conservation, 141-148.

Thompson, C. W. (1998). International prototypes and local identity: The walled garden of Scotland as heritage landscape. International Journal of Heritage Studies, 4(2), 64-72.

UNESCO (2013) New Life for Historic Cities: The Historic Urban Landscape Approach Explained. Paris: UNESCO.

Ward, C. and Wilkinson, A. (2006) Conducting meaningful interpretation: A field guide for success. Golden: Fulcrum Publishing.

Willis, K. G. (2009). Assessing visitor preferences in the management of archaeological and heritage attractions: a case study of Hadrian's Roman Wall. International Journal of Tourism Research, 11(5), 487-505.

Wolf, I. D., Stricker, H. K. and Hagenloh, G. (2013) Interpretive Media that Attract Park Visitors and Enhance Their Experiences: A Comparison of Modern and Traditional Tools Using GPS Tracking and GIS Technology, Tourism Management Perspectives, 7, pp.59-72

Yamada, N. and Knapp, D. H. (2009) Adult Participants' Preferences for Interpretation at a Japanese Nature Park, Journal of Interpretation Research, 14 (2), pp.59-67

Yankholmes, A. K., \& Akyeampong, O. A. (2010). Tourists' perceptions of heritage tourism development in Danish-Osu, Ghana. International Journal of Tourism Research, 12(5), 603-616. 


\section{Appendix 1 - Wrest Park Visitor Questionnaire}

\section{Wrest Park - Visitor Questionnaire}

\section{Pre-interview questions}

- Is this your first visit to Wrest Park?

- Are you member of English Heritage?

- Who did you came with? Family or friends?

Question 1. What is the purpose of your visit to Wrest Park? Is it because you enjoy days out in the countryside or perhaps, because you would like to learn more about this historic garden's history and significance?

Question 2. Have you used any of the interpretation methods provided on site, such as the Audio Guides, Children's Trails, Interactives, Guided Tours or the Exhibition?

2.1 If yes, did you enjoy the particular experience?

2.2 What was the one thing you liked the most about your engagement with the interpretation method(s)?

2.3 Thinking about your experience of using interpretation methods, what could be improved or done differently to enhance your visitor experience?

Question 3. What did you learn from your experience at Wrest Park? Did you learn something new about the history and significance of the place? If yes, tell us more. 